Stanisław Wanat

Monika Papież

Stawomir Śmiech

Department of Statistics

Cracow University of Economics

\title{
The Conditional Dependence Structure between Precious Metals: A Copula-GARCH Approach*
}

\begin{abstract}
The aim of the paper is to analyse the conditional dependence structure between precious metal returns using a copula-DCC-GARCH approach. Conditional correlation matrices are used to identify the states of the precious metals market by assuming that a given state of the market corresponds to a typical pattern of the conditional dependence structure. Cluster analysis allows for pointing at transition points between the market states, that is the points of drastic change in the conditional dependence structure. The application of the methodology described above to the period between 1997 and 2013 indicates three market states of four major precious metals (gold, silver, platinum and palladium). The results obtained reveal a sudden increase in dependencies between precious metals at the turn of April and May 2004.
\end{abstract}

Keywords: precious metals, dependence structure, copula-GARCH, market states.

\footnotetext{
* Supported by the grant No. 2012/07/B/HS4/00700 of the Polish National Science Centre.
} 


\section{Introduction}

Gold, platinum, palladium and silver are the most common precious metals. For centuries they have been primarily used to make jewellery, while nowadays they also play an important part in various industries. For example, gold is used in electronics, telecommunications and aviation, silver is used in the electronics and electrical industries (mobile phones, computer hardware), and, to a smaller extent, in photography. Platinum is mostly used in the chemical and petrochemical industries as a catalyst and in the motor industry for building catalytic converters, as well as in the electronic and electrical industries. In recent years these metals have become an important means of thesaurisation, and are now frequently used as an investment through, for instance, the purchase of gold bars or the purchase of precious metal-focused exchange traded funds. Such funds allow for the investment in metals without the need to actually possess them (iShares Gold Trust has been traded since January 2005 while the iShares Silver Trust was created in April 2006).

The existing research on precious metals focuses mainly on gold and silver. The analysis of the prices of precious metals can be divided into two areas. The first one covers the analysis of the relationship between prices of precious metals. C. Ciner (2001) finds evidence of the disappearance of the long-term relationship between gold and silver in the 1990s. His conclusion has been contested by B. M. Lucey and E. Tully (2006), who say that that relationship strengthens and weakens over time but prevails in the long run. Similarly, R. Sari, S. Hammoudeh and B. T. Ewing (2007) observe a strong relationship between gold and silver. S. Śmiech and M. Papież (2012) show that the causality between the prices of gold, silver, platinum and copper changed between 2000 and 2011. M. Papież and S. Śmiech (2012) have also examined causality in mean and variance between commodity prices (including metal prices) and financial market prices.

Another area of analysis examines the volatility of returns on these four precious metals. S. Hammoudeh and Y. Yuan (2008) showed that gold and silver have similar volatility persistence globally, but there is no leverage effect in gold and silver prices. R. Sari, S. Hammoudeh and U. Soytas (2010) examined the co-movements and information transmission among the spot prices of four precious metals (gold, silver, platinum, and palladium), the price of oil, and the US dollar/euro exchange rate. S. Hammoudeh et al. (2010) looked at the conditional volatility and correlation dependence for four major precious metals, and found that almost all of them are weakly responsive to news spilled over from other metals in the short run. L. Morales and B. Andreosso-O'Callaghan (2011) found that an asymmetric effect is observed where volatility spillovers are concerned. Gold tends to be the dominant market and the evidence favouring the case of other 
precious metals influencing the gold market is weak. S. J. Cochran, I. Mansur and B. Odusami (2012) showed that post-September 2008 events increased the volatility in gold, platinum, and silver returns. A. Sensoy (2013) claims that the turbulence that characterised 2008 did not have a significant effect on the volatility levels of gold and silver, though it caused an upward shift in the volatility of palladium and platinum. Using the consistent dynamic conditional correlations, he shows that precious metals became strongly correlated with each other during the last decade, which reduces the diversification benefits across them and indicates a convergence to a single asset class.

The objective of this study is to identify the states of the precious metals market (gold, silver, platinum and palladium) and to present their evolution in time for the period from September 22, 1997 to February 13, 2014. Since our sample period covers the recent global financial crisis, we want to examine whether the market states are affected by the financial crisis. The process of identifying the states of the precious metals market and analysing their temporal evolution is based on the conditional dependence structure using a copula-DCC-GARCH methodology.

This allows us to address several questions, which might be of interest to both investors and researchers:

- is the dependence between prices in the precious metals markets stable or does it undergo changes?

- are the changes in relations between precious metal prices evolutionary or drastic?

- what are the causes of drastic changes in relations between these prices?

The paper contributes to the existing literature in the following aspects. Firstly, most analyses of the precious metals market conducted so far have been based on standard multivariate GARCH (MGARCH) models (see e.g. Hammoudeh et al. 2010, Morales \& Andreosso-O'Callaghan 2011, Sensoy 2013, Silvennoinen \& Thorp 2013), all of which assume that standardised innovations follow a multivariate elliptical distribution. In the case of the multivariate normal distribution, all marginal distributions must be normal, and multivariate Student's t distribution imposes, also often unrealistically, the same degrees of freedom for all marginal distributions.

However, the copula-based multivariate GARCH model used in this study allows for modelling the conditional dependence structure when standardised innovations are non-elliptically distributed. Thus, it makes it possible to model the volatility of particular metals using univariate GARCH models with different standarised residual distribution. Generally, copulas allow the researcher to specify the models for the marginal distributions separately from the dependence structure that links these distributions to form a joint distribution. They offer a greater 
flexibility in modelling and estimating margins than do parametric multivariate distributions (see e.g. Nelsen 1999, Joe 1997).

Secondly, at present copula-GARCH methodology is widely used in the analysis of financial time series (see e.g. Patton 2006, Serban et al. 2007, Lee \& Long 2009, Doman 2011, Wu, Chung \& Chang 2012, Aloui, Ben Aïssa \& Nguyen 2013, Li \& Yang 2013, Philippas \& Siriopoulos 2013, Zolotko \& Okhrin 2014). For a review of the literature, see (Patton 2012). However, in most studies on the precious metals market, copula methodologies are used to analyse the dependencies between single metal markets and other markets (see e.g. Reboredo 2013a, 2013b). This study is based on conditional correlations using a copula-GARCH methodology to investigate the dynamics of the conditional dependence structure between precious metals. It also attempts to identify the states of the market on the basis of these conditional correlations and to follow their temporal evolution. To the best of our knowledge, such an approach has never been applied to investigate dependencies in the precious metals markets.

The paper is organised as follows. Section 2 describes the data and econometric methodologies employed, while the empirical results are discussed in Section 3 followed by the conclusions.

\section{Methodology}

The dynamic relationship between precious metals is analysed with the use of a copula-DCC-GARCH model for daily log-returns. In this approach, multivariate joint distributions of the return vector $r_{t}=\left(r_{1, t}, \ldots, r_{k, t}\right)^{\prime}, t=1, \ldots, T$, conditional on the information set available at time $t-1\left(\Omega_{t-1}\right)$ to be modelled using the conditional copulas introduced by Patton (2006). This model takes the following form:

$$
\begin{gathered}
r_{1, t}\left|\Omega_{t-1} \sim F_{1, t}\left(\cdot \mid \Omega_{t-1}\right), \ldots, r_{k, t}\right| \Omega_{t-1} \sim F_{k, t}\left(\cdot \mid \Omega_{t-1}\right) \\
r_{t} \mid \Omega_{t-1} \sim F_{t}\left(\cdot \mid \Omega_{t-1}\right) \\
F_{t}\left(r_{t} \mid \Omega_{t-1}\right)=C_{t}\left(F_{1, t}\left(r_{1, t} \mid \Omega_{t-1}\right), \ldots, F_{k, t}\left(r_{k, t} \mid \Omega_{t-1}\right) \mid \Omega_{t-1}\right),
\end{gathered}
$$

where $C_{t}$ denotes the copula, while $F_{t}$ and $F_{i, t}$ respectively - the joint cumulative distribution function and the cumulative distribution function of the marginal distributions at time $t$.

Univariate rates of return $r_{i, t}$ are modelled using ARMA-GARCH processes:

$$
\begin{aligned}
r_{i, t} & =\mu_{i, t}+y_{i, t}, \\
\mu_{i, t}=E\left(r_{i, t} \mid \Omega_{t-1}\right), \mu_{i, t} & =\mu_{i 0}+\sum_{j=1}^{P_{i}} \varphi_{i j} r_{i, t-j}+\sum_{j=1}^{Q_{i}} \theta_{i j} y_{i, t-j},
\end{aligned}
$$




$$
\begin{gathered}
y_{i, t}=\sqrt{h_{i, t}} z_{i, t}, \\
h_{i, t}=\operatorname{Var}\left(r_{i, t} \mid \Omega_{t-1}\right), h_{i, t}=\omega_{i}+\sum_{j=1}^{p_{i}} \alpha_{i j} y_{i, t-j}^{2}+\sum_{j=1}^{q_{i}} \beta_{i j} h_{i, t-j},
\end{gathered}
$$

where $z_{i, t}$ are i.i.d. random variables which conditionally follow some distributions with the required properties (in the empirical analysis the following distributions are considered: normal distibution, skew-normal distribution, student- $t$, skew-student, generalised error distribution).

The dependence structure of the margins is then assumed to follow an elliptical copula ${ }^{1}$ with conditional correlations $R_{t}$. The dynamics of $R_{t}$ is modelled with the use of the dynamic conditional correlation model DCC $(m, n)$ :

$$
\begin{gathered}
H_{t}=D_{t} R_{t} D_{t}, \\
D_{t}=\operatorname{diag}\left(\sqrt{h_{1, t}}, \ldots, \sqrt{h_{k, t}}\right), \\
R_{t}=\left(\operatorname{diag}\left(Q_{t}\right)\right)^{-1 / 2} Q_{t}\left(\operatorname{diag}\left(Q_{t}\right)\right)^{-1 / 2}, \\
Q_{t}=\left(1-\sum_{j=1}^{m} c_{j}-\sum_{j=1}^{n} d_{j}\right) \bar{Q}+\sum_{k=1}^{m} c_{j}\left(\varepsilon_{t-j} \varepsilon_{t-j}^{\prime}\right)+\sum_{k=1}^{n} d_{j} Q_{t-j},
\end{gathered}
$$

where conditional variances $h_{i, t}$ are modelled with the use of one-dimensional $\operatorname{GARCH}(p, q)$ processes $(7), \varepsilon_{t}=D_{t}^{-1} y_{t}\left(y_{t}=\left(y_{1, t}, \ldots, y_{k, t}\right)^{\prime}\right)$ and $\bar{Q}$ is an unconditional covariance matrix of standardised residuals $\varepsilon_{t}$. In specification (12) $c_{j}(j=1$, $\ldots, m), d_{j}(j=1, \ldots, n)$ are scalars which capture, respectively, the effect of previous shocks and previous dynamic correlation on the current conditional correlation.

The parameters of the above copula-DCC-GARCH model are assessed using an inference function for margins (IFM) approach ${ }^{2}$. Calculations were made in the $R$ package (,rmgarch”, version 1.2-6) developed by Alexios Ghalanos.

The states of the precious metals market are identified on the basis of conditional correlation matrices. It is assumed that a given market state corresponds to a typical pattern of the conditional dependence structure described by a conditional correlation matrix $R_{t}$. Transition points between market states, corresponding to drastic changes in the conditional dependence structure, are identified

1 The paper presents the results of the first stage of research, in which a relatively simple approach for investigating dependencies among precious metals was used. In this approach conditional correlation matrices modelled with the use of DCC model are applied in a natural way as parameters of dynamic elliptical copulas (it seems a natural extension of the 2-stage DCC model). During the next stage of the research, the authors use more complicated dependence structures (e.g. hierarchical Archimedean copulas, Vine copulas). The results obtained will be presented in the next paper.

2 This method is described in detail in (Joe 1997, pp. 299-307; Doman 2011, pp. 35-37, and Wanat 2012, pp. 98-99). 
using Ward's method of cluster analysis and a similarity measure suggested by M. C. Münnix et al. (2012), which allows us to quantify the difference of the correlation structure for two points in time.

\section{Data and Empirical Results}

The data used in this study consist of the daily (five working days per week) spot prices of gold (Gold), silver (Silv), platinum (Plat) and palladium (Pall) from September 22, 1997 to February 13, 2014 (see Fig. 1). The source of data is Bloomberg, and all prices of precious metals are measured in US dollars per troy ounce. As is traditionally done, price return series are computed on a continuous compounding basis as $r_{i, t}=100 \times\left(\log \left(P_{i, t} / P_{i, t-1}\right)\right)$, where $P_{i, t}$ and $P_{i, t-1}$ are current and one-period lagged spot prices of precious metals. After eliminating the mismatching transaction days, we end up with 4185 log-returns for each series (see Fig. 2).

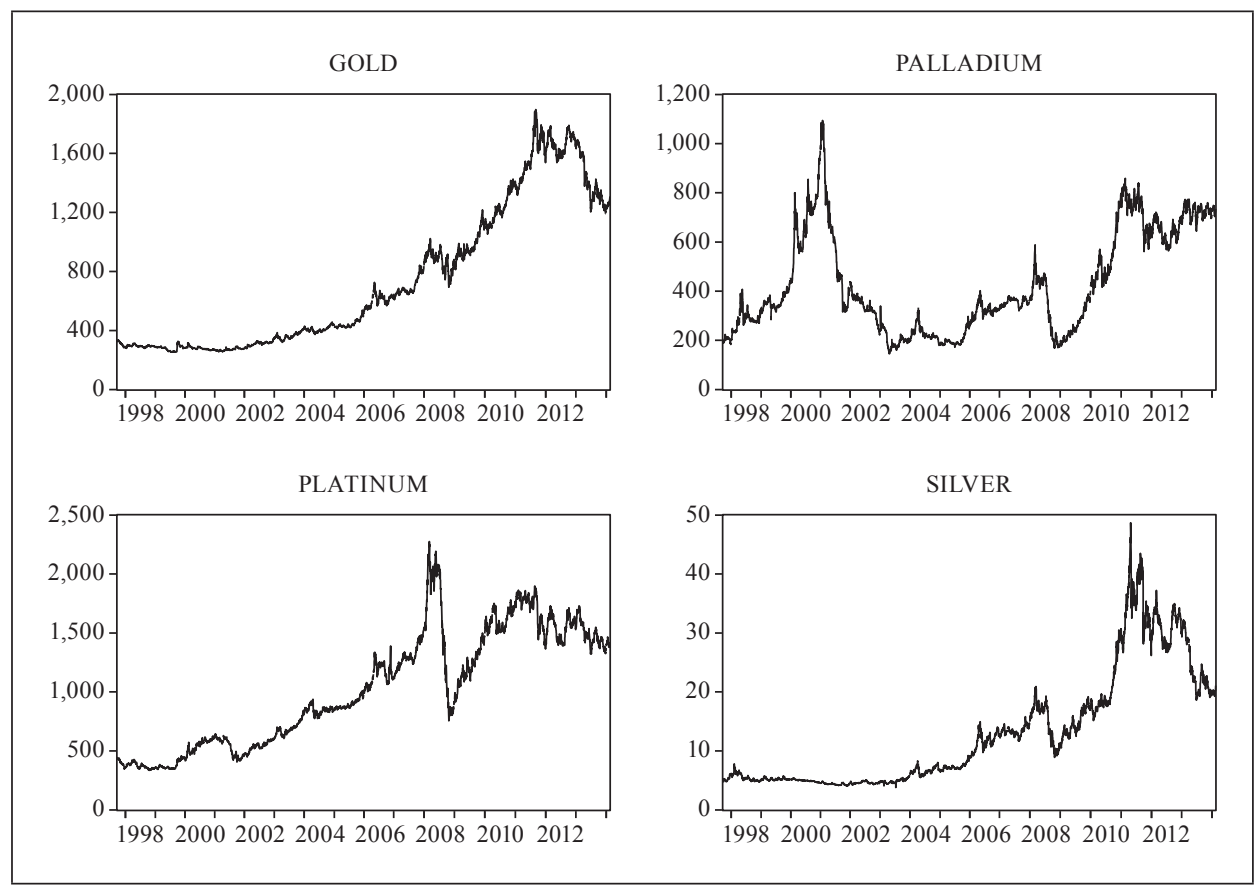

Fig. 1. Price Series of Major Precious Metals between September 1997 and February 2014 Source: the authors' own calculations. 


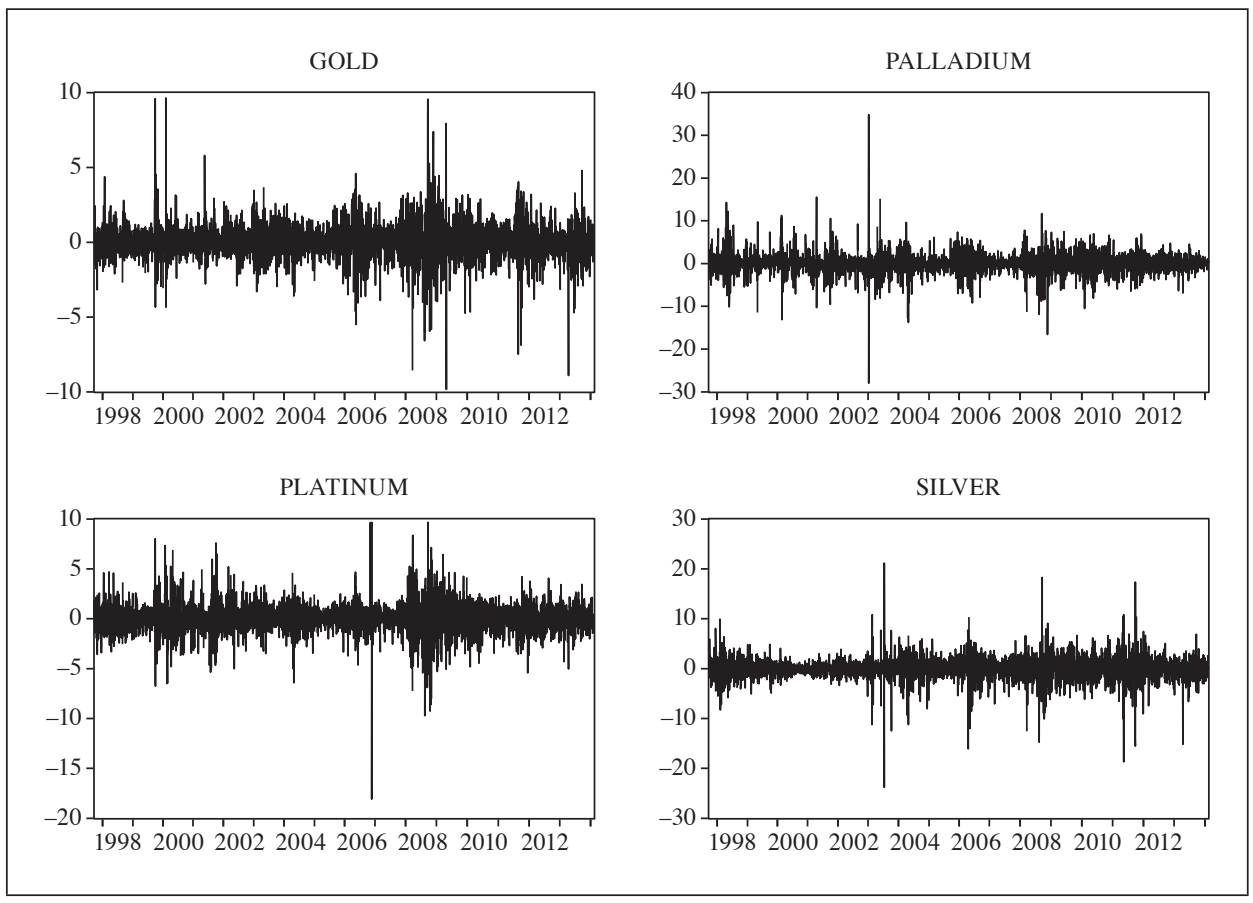

Fig. 2. Returns on Major Precious Metals between September 1997 and February 2014 Source: the authors' own calculations.

The descriptive statistics for the metals' price levels in U.S. dollar and the returns are reported (in level form) in Tables 1a and 1b, respectively.

Table 1a. Descriptive Statistics for Levels

\begin{tabular}{|l|r|r|r|r|}
\hline \multicolumn{1}{|c|}{ Specification } & \multicolumn{1}{c|}{ Gold } & Palladium & Platinum & Silver \\
\hline Mean & 730.39 & 425.16 & 1021.36 & 13.02 \\
\hline Median & 520.75 & 354.50 & 929.00 & 8.83 \\
\hline Max & 1896.50 & 1094.00 & 2276.00 & 48.70 \\
\hline Min & 252.90 & 144.00 & 335.00 & 3.78 \\
\hline Std. Dev. & 485.76 & 205.61 & 489.60 & 9.80 \\
\hline Skewness & 0.79 & 0.71 & 0.24 & 1.16 \\
\hline Kurtosis & 2.22 & 2.38 & 1.81 & 3.34 \\
\hline
\end{tabular}

Source: the authors' own calculations. 
Table 1b. Descriptive Statistics for Returns

\begin{tabular}{|l|r|r|r|r|}
\hline \multicolumn{1}{|c|}{ Specification } & \multicolumn{1}{c|}{ Gold } & Palladium & \multicolumn{1}{c|}{ Platinum } & \multicolumn{1}{c|}{ Silver } \\
\hline Mean & 0.03323 & 0.03129 & 0.02779 & 0.03486 \\
\hline Median & 0.02535 & 0.00000 & 0.00000 & 0.04999 \\
\hline Max & 9.64163 & 34.83067 & 9.67362 & 21.14351 \\
\hline Min & -9.84051 & -27.98695 & -18.08837 & -23.78497 \\
\hline Std. Dev. & 1.18972 & 2.37340 & 1.50888 & 2.20188 \\
\hline Skewness & -0.10254 & 0.25457 & -0.40458 & -0.60756 \\
\hline Kurtosis & 11.66950 & 22.93386 & 12.87393 & 16.53494 \\
\hline
\end{tabular}

Source: the authors' own calculations.

The statistics for the metals' returns generally follow those for their prices. The return on palladium historically has the highest volatility followed by silver, while gold returns are the least volatile of the four metals. In terms of historical return means, silver has the highest average return, followed by gold and palladium, while platinum has the lowest averages.

Table 2. Copula-DCC-GARCH Parameters for Log-returns

\begin{tabular}{|c|c|c|c|c|c|}
\hline \multicolumn{2}{|c|}{ Parameter } & Estimate & Std. Error & $t$ value & $\operatorname{Pr}(>|t|)$ \\
\hline \multirow{6}{*}{ Gold } & $\mu_{0}$ & 0.029086 & 0.012316 & 2.361737 & 0.018190 \\
\hline & $\varphi_{1}$ & -0.049451 & 0.015856 & -3.118691 & 0.001817 \\
\hline & $\omega$ & 0.020068 & 0.005796 & 3.462679 & 0.000535 \\
\hline & $\alpha_{1}$ & 0.073493 & 0.012870 & 5.710575 & 0.000000 \\
\hline & $\beta_{1}$ & 0.914029 & 0.014309 & 63.878167 & 0.000000 \\
\hline & $v$ & 4.830476 & 0.386835 & 12.487167 & 0.000000 \\
\hline \multirow{5}{*}{ Silver } & $\mu_{0}$ & -0.002054 & 0.026160 & -0.078522 & 0.937413 \\
\hline & $\varphi_{1}$ & -0.084966 & 0.023533 & -3.610577 & 0.000306 \\
\hline & $\omega$ & 0.014193 & 0.007579 & 1.872632 & 0.061119 \\
\hline & $\alpha_{1}$ & 0.042194 & 0.003504 & 12.041960 & 0.000000 \\
\hline & $\beta_{1}$ & 0.956806 & 0.003013 & 317.543829 & 0.000000 \\
\hline \multirow{6}{*}{ Platinum } & $\mu_{0}$ & 0.046781 & 0.017618 & 2.655337 & 0.007923 \\
\hline & $\varphi_{1}$ & -0.524437 & 0.127566 & -4.111113 & 0.000039 \\
\hline & $\theta_{1}$ & 0.541134 & 0.124888 & 4.332960 & 0.000015 \\
\hline & $\omega$ & 0.055136 & 0.020305 & 2.715404 & 0.006620 \\
\hline & $\alpha_{1}$ & 0.112217 & 0.023435 & 4.788354 & 0.000002 \\
\hline & $\beta_{1}$ & 0.866600 & 0.029305 & 29.571831 & 0.000000 \\
\hline
\end{tabular}


Table 2 cnt'd

\begin{tabular}{|c|c|c|c|r|c|}
\hline \multicolumn{2}{|c|}{ Parameter } & Estimate & Std. Error & \multicolumn{1}{c|}{$t$ value } & $\operatorname{Pr}(>|t|)$ \\
\hline \multirow{5}{*}{} & $\xi$ & 0.993258 & 0.020038 & 49.569488 & 0.000000 \\
\cline { 2 - 6 } & $v$ & 5.425853 & 0.443948 & 12.221817 & 0.000000 \\
\hline \multirow{5}{*}{ Palladium } & $\mu_{0}$ & 0.038276 & 0.023363 & 1.638314 & 0.101356 \\
\cline { 2 - 6 } & $\varphi_{1}$ & 0.050001 & 0.016266 & 3.073882 & 0.002113 \\
\cline { 2 - 6 } & $\omega$ & 0.207753 & 0.046007 & 4.515633 & 0.000006 \\
\cline { 2 - 6 } & $\alpha_{1}$ & 0.212891 & 0.027570 & 7.721894 & 0.000000 \\
\cline { 2 - 6 } & $\beta_{1}$ & 0.784233 & 0.024263 & 32.322346 & 0.000000 \\
\cline { 2 - 6 } Joint (DCC) & $v$ & 3.900838 & 0.259408 & 15.037464 & 0.000000 \\
\cline { 2 - 6 } & $c_{1}$ & 0.021455 & 0.002566 & 8.360567 & 0.000000 \\
\cline { 2 - 6 } & $d_{1}$ & 0.973780 & 0.003508 & 277.586697 & 0.000000 \\
\hline
\end{tabular}

Source: the authors' own calculations.

In the empirical study, different variants of the ARMA-GARCH specification are considered for individual returns. Eventually, on the basis of information criteria, Student's $t$ (with shape parameter $v$ ) AR(1)-GARCH(1,1) model was assumed for gold; the normal AR(1)-GARCH(1,1) model for silver; skewed Student's $t$ (with skew and shape parameters $\xi$ and $v$ respectively) ARMA $(1,1)-$ -GARCH(1,1) model for platinum; and Student's $t$ (with shape parameter $v$ ) AR(1)-GARCH(1,1) model was assumed for palladium. On the other hand, Gauss and Student's $t$ copulas were considered in the analysis of the dynamics of dependencies between the rates of return, and, also on the basis of information criteria, Student's $t$ with conditional correlation and constant shape parameter $\eta$ was chosen ${ }^{3}$.

Conditional correlation matrices obtained with the use of the estimated model were applied to analyse the precious metals market. Dynamic correlations in this market are presented in Fig. 3. Fig. 4 shows the temporal evolution of the market states in the period from September 22, 1977 to February 13, 2014, obtained as a result of clustering conditional correlation matrices with Ward's method of cluster analysis. The left panel illustrates the division into two clusters (Rousseeuw's Silhouette internal cluster quality index equals 0.5512), while the right panel illustrates the division into three clusters (Rousseeuw's Silhouette internal cluster quality index equals 0.3169 ). Structural changes in the precious metals markets in the analysed period are identified with the use of a similarity measure of correlation matrices (Münnix et al. 2012) and presented in Fig. 5 (the left panel

${ }^{3}$ The results can be obtained from the author on request. 
illustrates the similarity of matrices distant from each other by a multiple of one quarter, while the right panel shows a multiple of one year). Light shading denotes similar conditional correlation matrices and dark shading denotes dissimilar ones. If we assume that a point on the diagonal designates "now", then the similarity to previous times from this point can be found on the vertical line below this point, or the horizontal line to the left of it.

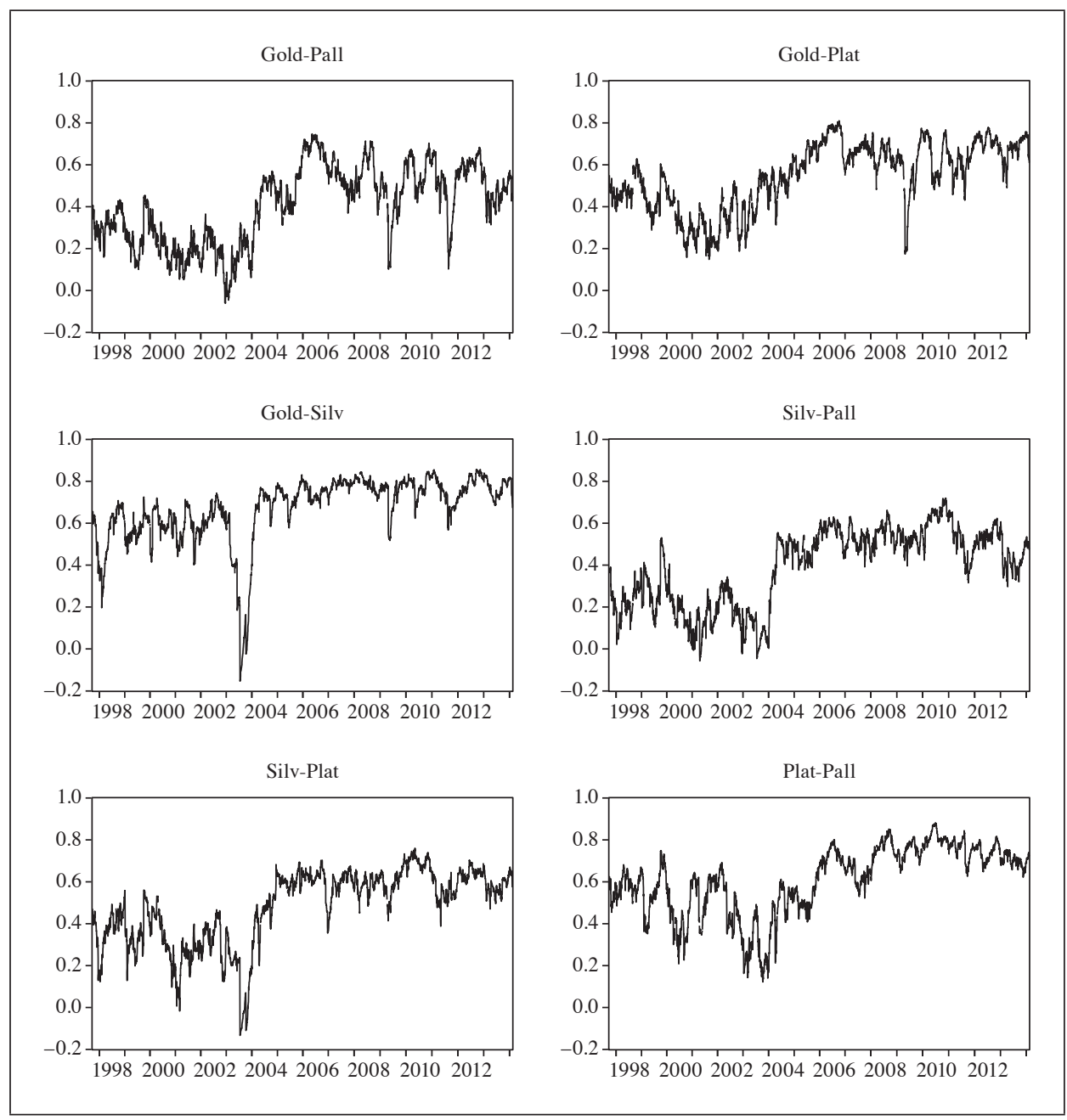

Fig. 3. Dynamic Correlations of Precious Metal Returns

Source: the authors' own calculations. 


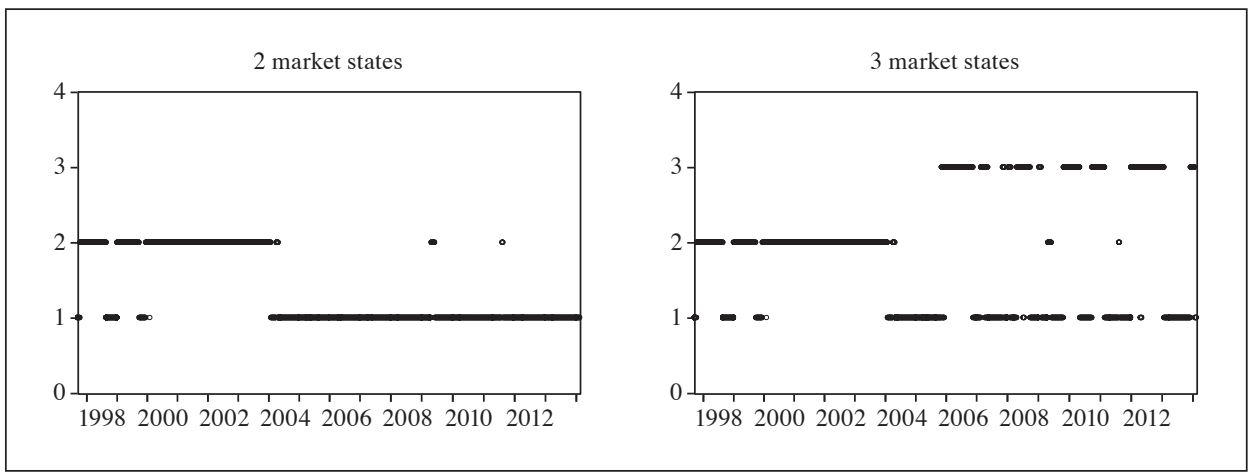

Fig. 4. Temporal Evolution of the Market State

Source: the authors' own calculation.

After analysing the dynamics of conditional correlation matrices (Fig. 3), it can be said that bilateral correlation between precious metals markets increased considerably in 2004 and has remained at this level since then. A similar conclusion can be drawn from the analysis of similarity maps showing conditional correlation matrices (Fig. 5). Particular areas in the matrix show how similar dependence measures in two periods are: the first one is on the horizontal axis and the second one on the vertical axis. Fig. 5 presents the results for two options: the first option covers correlations calculated for sub-periods with 70 observations, and the second for sub-periods with 250 observations. The low value of the similarity measure of correlation matrices (considerably darker shading) for 2004 together with its rise and the maintenance of this high level (lighter shading) indicate structural changes in precious metals markets in 2004. This confirms A. Sensoy's (2013) hypothesis that precious metals will be a single asset class in the near future. This change in the precious metals markets in 2004 is also evident in clustering results (Fig. 4). Divisions into two and three clusters indicate a stable change of the market state in April 29, 2004. For the last decade this market has not returned (with few exceptions) to the state it enjoyed before April 29, 2004. The more detailed analysis of this decade (the division into 3 clusters) reveals two basis states with numerous transition points between them. On the basis of the results obtained, it can be concluded that the global financial crisis from 2008 has not considerably affected the precious metals market. 


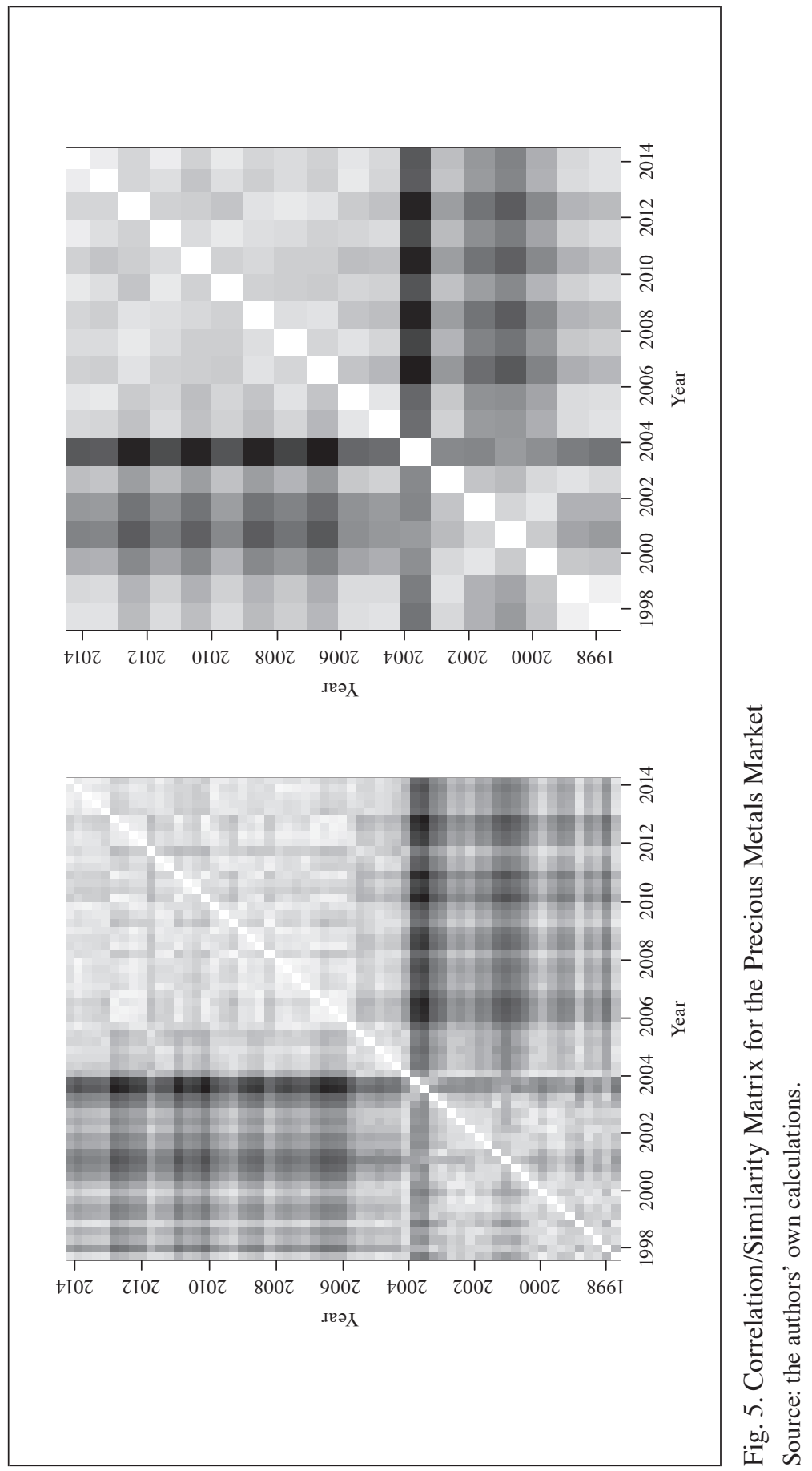




\section{Conclusion}

The objective of this study was to analyse the conditional dependence structure between precious metals using copula-DCC-GARCH methodology and to follow the metals' temporal evolution. The results obtained in the study reveal that the dependence structure is not stable over time. Internal clustering criteria applied to Ward's method prove that two (which seems to be the better choice) or three typical patterns of the conditional dependence are plausible. If two market states are assumed, the transition point takes place in April 2004. The state of the precious metals market before and after this moment is stable, with rare and transitory changes. Conditional correlations in the first period are lower than in the second period. If three market states are assumed, the one that ran until April 2004 is stable, but two patterns that changed frequently were later observed. The similarity between these two last states are, however, quite high. Summing up, the results obtained indicate that the dependence structure of precious metals undergoes only one drastic structural change, in April 2004. This confirms A. Sensoy's (2013) hypothesis that precious metals will be a single asset class in the near future. A unique opportunity to test this thesis was the global financial crisis, which, however, did not affect the correlation structure of returns on precious metals. The results obtained might be of great importance to investors, as they demonstrate that drastic changes of the correlation structure of the precious metals market is currently highly unlikely.

\section{Bibliography}

Aloui R., Ben Aïssa M. S., Nguyen D. K. (2013), Conditional Dependence Structure between Oil Prices and Exchange Rates: A Copula-GARCH Approach, "Journal of International Money and Finance", vol. 32: 719-738.

Ciner C. (2001), On the Long-run Relationship between Gold and Silver Prices: A Note, "Global Finance Journal", vol. 12: 299-303, http://dx.doi.org/10.1016/S10440283(01)00034-5.

Cochran S. J., Mansur I., Odusami B. (2012), Volatility Persistence in Metal Returns: A FIGARCH Approach, "Journal of Economics and Business", vol. 64: 287-305.

Doman R. (2011), Zastosowanie kopuli w modelowaniu dynamiki zależności na rynkach finansowych, Wydawnictwo Uniwersytetu Ekonomicznego w Poznaniu, Poznań.

Engle R. (2002), Dynamic Conditional Correlation: A Simple Class of Multivariate Generalized Autoregressive Conditional Heteroskedasticity Models, "Journal of Business \& Economic Statistics", vol. 20: 339-350.

Hammoudeh S., Yuan Y. (2008), Metal Volatility in Presence of Oil and Interest Rate Shocks, "Energy Economics", vol. 30: 606-620, http://dx.doi.org/10.1016/j.eneco. 2007.09.004. 
Hammoudeh S., Yuan Y., McAleer M., Thompson M.A. (2010), Precious Metals-exchange Rate Volatility Transmissions and Hedging Strategies, "International Review of Economics \& Finance", vol. 19: 633-647.

Joe H. (1997), Multivariate Models and Dependence Concepts, Chapman-Hall, London.

Lee T.-H., Long X. (2009), Copula-based Multivariate GARCH Model with Uncorrelated Dependent Errors, "Journal of Econometrics", vol. 150: 207-218, http://dx.doi. org/10.1016/j.jeconom.2008.12.008.

Li M., Yang L. (2013), Modeling the Volatility of Futures Return in Rubber and OilA Copula-based GARCH Model Approach, "Economic Modelling", vol. 35: 576-581.

Lucey B. M. and Tully E. (2006), The Evolving Relationship between Gold and Silver 1978-2002: Evidence from a Dynamic Cointegration Analysis: A Note, "Applied Financial Economics Letters", vol. 2: 47-53.

Morales L., Andreosso-O'Callaghan B. (2011), Comparative Analysis on the Effects of the Asian and Global Financial Crises on Precious Metal Markets, "Research in International Business and Finance", vol. 25: 203-227.

Münnix M. C., Shimada T., Schäfer R., Leyvraz F., Seligman T. H., Guhr T., Stanley H. E. (2012), Identifying States of a Financial Market, "Scientific Reports", vol. 2, http:// dx.doi.org/10.1038/srep00644.

Nelsen R. B. (1999), An Introduction to Copulas, Springer-Verlag, New York.

Papież M., Śmiech S. (2012), Causality in Mean and Variance Between Returns of Crude Oil and Metal Prices, Agricultural Prices and Financial Market Prices (in:) J. Ramík, D. Stavárek (eds), Proceedings of 30th International Conference Mathematical Methods in Economics, Silesian University, School of Business Administration, Karviná: 675-680.

Patton A. J. (2006), Modelling Asymmetric Exchange Rate, "International Economic Review", vol. 47: 527-556.

Patton A. J. (2012), A Review of Copula Models for Economic Time Series, "Journal of Multivariate Analysis", vol. 110: 4-18, http://dx.doi.org/10.1016/j.jmva.2012.02.021.

Philippas D., Siriopoulos C. (2013), Putting the " $C$ " into Crisis: Contagion, Correlations and Copulas on EMU Bond Markets, "Journal of International Financial Markets, Institutions and Money", vol. 27: 161-176.

Reboredo J. C. (2013a), Is Gold a Hedge or Safe Haven Against Oil Price Movements? "Resources Policy", vol. 38: 130-137.

Reboredo J. C. (2013b), Is Gold a Safe Haven or a Hedge for the US Dollar? Implications for Risk Management, "Journal of Banking and Finance", vol. 37: 2665-2676.

Sari R., Hammoudeh S., Ewing B. T. (2007), Dynamic Relationships between Oil and Metal Commodity Futures Prices, "Geopolitics of Energy", vol. 29: 2-13.

Sari R., Hammoudeh S., Soytas U. (2010), Dynamics of Oil Price, Precious Metal Prices, and Exchange Rate, "Energy Economics", vol. 32: 351-362, http://dx.doi.org/10.1016/j. eneco.2009.08.010.

Sensoy A. (2013), Dynamic Relationship between Precious Metals, "Resources Policy", vol. 38: 504-511, http://dx.doi.org/10.1016/j.resourpol.2013.08.004.

Serban M., Brockwell A., Lehoczky J., Srivastava S. (2007), Modelling the Dynamic Dependence Structure in Multivariate Financial Time Series, "Journal of Time Series Analysis", vol. 28: 763-782, http://dx.doi.org/10.1111/j.1467-9892.2007.00543.x. 
Silvennoinen A., Thorp S. (2013), Financialization, Crisis and Commodity Correlation Dynamics, "Journal of International Financial Markets, Institutions and Money", vol. 24: 42-65.

Śmiech S., Papież M. (2012), A Dynamic Analysis of Causality between Prices on the Metals Market (in:) M. Reiff (ed.),Proceedings of the International Conference Quantitative Methods in Economics (Multiple Criteria Decision Making XVI), Bratislava: 221-225.

Wanat S. (2012), Modele zależności w agregacji ryzyka ubezpieczyciela, Wydawnictwo Uniwersytetu Ekonomicznego w Krakowie, Kraków.

Wu C. C., Chung H., Chang Y. H. (2012), The Economic Value of Co-movement between Oil Price and Exchange Rate using Copula-based GARCH Models, "Energy Economics", vol. 34: 270-282, http://dx.doi.org/10.1016/j.eneco.2011.07.007.

Zolotko M., Okhrin O. (2014), Modelling the General Dependence between Commodity Forward Curves, "Energy Economics", vol. 43: 284-296, http://dx.doi.org/10.1016/j. eneco.2014.02.019.

\section{Modelowanie warunkowej zależności między metalami szlachetnymi z wykorzystaniem modeli copula-GARCH}

(Streszczenie)

W pracy analizowano warunkową strukturę zależności na rynku metali szlachetnych z wykorzystaniem modeli copula-DCC-GARCH. Na podstawie warunkowych macierzy korelacji rozpoznano stany rynku metali szlachetnych. W tym celu przyjęto, że określonemu stanowi rynku odpowiada typowy wzór warunkowej struktury zależności. Momenty przejścia pomiędzy poszczególnymi stanami odpowiadające nagłym (drastycznym) zmianom w warunkowej strukturze zależności zidentyfikowano, wykorzystując metody grupowania. Zastosowanie opisanej metodologii pozwoliło w okresie od 1997 r. do 2013 r. wyodrębnić trzy stany rynku czterech metali szlachetnych (złoto, srebro, platyna, pallad). Badania wskazały także na znaczny wzrost zależności między rozważanymi metalami na przełomie kwietnia i maja 2004 r.

Słowa kluczowe: metale szlachetne, struktura zależności, copula-GARCH, stany rynku. 